\title{
Students' Perceptions on a Good Tertiary Foreign Language Teacher
}

\section{Siti Tarwiyah}

IAIN Walisongo Semarang

Jl. Walisongo 3-5 Semarang

nashidadear@yahoo.co.id

\section{Nadiah Ma'mun}

IAIN Walisongo Semarang

Jl. Walisongo 3-5 Semarang

nadiah.mamun@facebook.com

\section{Abstract}

This paper investigates students' perception of tertiary teachers' attitude, method of teaching and classroom management in the teaching and learning of (professional, pedagogic, social and personality competence) English and Arabic Language at IAIN Walisongo Semarang. This study is designed quantitavely and qualitatively using closed and open-ended questionnaire for collecting data. The subject of this research is the second semester students of the two faculties at IAIN Walisongo who, in that semester, take Arabic or English language course. The subject is chosen because based on 2012 course distribution, English and Arabic are distributed in the first and the second semester. The findings revealed that it is clearly seen that KPI (Islamic Communication \& Broadcasting) department students have better perception to their English language teachers. Meanwhile, students who have better perception to their Arabic Language Teachers are those from Islamic Counseling Departments (BPI) 
of Dakwah faculty. Data of Tarbiyah Faculty shows Arabic language teachers are dominating. Arabic language teachers win 0.5 over English language teachers in almost all characteristics. This implies that expected performance of students in English Language is based on the teachers' attitude, method of teaching the subject and classroom management. Based on the above-findings, recommendations were made.

Keywords: Perception, Tertiary Teachers, Personality Social and Pedagogic Competence, English Language, Teaching/Learning

\begin{abstract}
Abstrak
Makalah ini mengkaji persepsi mahasiswa terhadap kompetensi sikap, metode pembelajaran, dan manajemen kelas dosen mata kuliah Bahasa Inggris dan Bahasa Arab di IAIN Walisongo Semarang. Kajian ini didesain secara kuantitatif dan kualitatif, dengan menggunakan kuesioner tertutup dan terbuka sebagai teknik pengumpulan data. Subyek penelitian ini adalah mahasiswa IAIN Walisongo semester dua dari dua fakultas, yaitu Fakultas Dakwah dan Fakultas Tarbiyah. Subyek ini diambil karena pada semester tersebut mereka sudah mengambil Bahasa Arab dan Bahasa Inggris. Hasil kajian menunjukkan bahwa mahasiswa Komunikasi dan Penyiaran Islam (KPI) mempunyai persepsi yang lebih baik terhadap dosen Bahasa Inggris, sedangkan mahasiswa Bimbingan Islam (BPI) memandang dosen Bahasa Arab mereka yang lebih baik. Data dari Fakultas Tarbiyah menunjukkkan bahwa dosen Bahasa Arab lebih mendapat tempat dalam hampir seluruh karakterisrik yang dikaji.
\end{abstract}

Kata kunci: Persepsi, Kompetensi Sikap, Sosial dan Pengajaran, Bahasa Inggris, Pembelajaran

\title{
Introduction
}

Teaching a foreign language is considered to be one of the most challenging teaching practices. In Indonesia, students are usually afraid 
of joining foreign language classes. They may feel unmotivated, discouraged easily. Their minds say foreign language is difficult to learn because most of them know little thing or even nothing from the start. These phenomena should be taken into account by English and Arabic language teachers both at schools and at universities.

In the teaching and learning process, teachers of English and Arabic Language as foreign/second language (FL/SL) have an important role in helping learners to learn. English and Arabic Language teachers must be able to create good atmosphere of language class and engage students' motivation in learning them so that they can enjoy learning. This situation will automatically facilitate students' understanding and support the realization of learning aims.

It is believed that personal, pedagogical, intellectual/professional, and social capacity support teachers in conducting their teaching. A foreign language teacher with good competency will be able to cope with the following compelling factors:

1. Insufficient foreign language competence

2. The lack of knowledge and skill about the latest concept of foreign language teaching.

3. The use of new books which the teachers must familiarize themselves and manage to master the contents.

4. Monotonous teaching style results from insufficient knowledge about various media and method.

5. Poor personality which will impact students' attitude to the language classes.

6. Poor classroom management which will influence the classroom atmosphere. 
Good foreign language teachers manage to conduct teaching learning process based on language teaching principles. To make sure whether the process is done appropriately, supervision is demanded.

Supervision of teaching learning process becomes an art of the work of the quality assurance board of a school. It is done by Lembaga Penjamin Mutu Pendidikan, school supervisor, headmaster, and teachers of the same subjects. The results of the supervision are, then, brought into the focus-group discussion among the elements involved. The discussion results in some recommendation for the future improvement of the teaching learning process.

In another way it may be said that teaching learning needs preparation or plan which covers identification of learning aims, materials, methods, sources, and assessment. The implemented plan is then learnt to identify the strength and the weaknesses. The weaknesses becomes the room for improvement in the next teaching, especially when the teacher teaches the same materials.

On the other hand, it is still perceived that many English language teachers in Indonesia are not effective teachers. They do not have adequate teaching skills and knowledge of subject matters, which are indicators of effective teachers (Hay McBer, 2000). The same case tend also to happend in Arabic language class.

The second semester students of all faculties at IAIN Walisongo attend English or Arabic language class, since both courses are offered in the first and the second semester. Students as the subject of teaching, in a learner-centred class, must be aware of the importance of good lecturer, must be critical of their teachers' competence. A class with a good lecturer will be a class with good output. On the other hands $60 \%$ of 
Arabic (35) and English language teachers (28) at IAIN Walisongo, where the study was conducted, do not have either English or Arabic Education background. This condition may influence teaching capacity of the teachers.

On the base of that notion, this research is considered to be important input for Centre for Language and Culture as the coordinator of foreign language teacher and teaching at IAIN Walisongo especially in the effort of having English and Arabic language teachers that meet the demands of good teachers as proposed by students and concepts of teacher competences. After being aware of the importance of having the characteristics of good language teacher, the researcher hopes that the centre will upgrade its foreign language teachers' competence and the teachers will also try to equip themselves with those characteristics.

\section{Perception}

Some studies on perception on teaching learning processes had been conducted cited for this study. Among all of them are "Good Language Teachers", Whose Perception?, done by Ani Purjayanti (2007) at Bogor Agricultural University, What Is a Good Language Teacher?: Students' and Teachers' Reflection, conducted by listyani at satya Wacana Christion University Salatiga, and Conceptions of a Good Tertiary EFL Teachers in China, studied by Qunying Zhang and David Watkins (2007) at University of Hongkong.

Hoffman said that perception aims at estimating true properties of the world. Perception usually results in cathegorization, which is in fact the classification of the world itself. ... perceptions usually hide the complexity of the world and guides adaptive behaviour (Hoffman, 
2013:1). The way a person conceives and perceives something are usually influenced by the background knowledge of thing being highlighted and the person's needs and interest. The wider knowledge $\mathrm{s} /$ he has the more comprehensive she/he will see the target. Nevertheless her/his view may be made blurred because of her/his needs and interest.

\section{Good language teacher}

The perception of good teacher comprises personal and teaching characteristics. Directorate General of Higher Education (2006) had done a survey about students' expectation towards toward their teachers. It indicates that a teacher should be clever/knowledgeable (pintar), knowledgeable in their subjects (menguasai ilmu-ilmu yang diajarkan), explain difficult points in an easy way (menjelaskan hal-hal yang sulit dengan cara yang mudah, patient and not cynical (sabar dan tidak sinis), have broad experiences/minded (mempunyai pengalaman yang luas), active in academic society (terkenal di masyarakat ilmiah), have a sense of humour (humoris), not to test students' weaknesses in their lesson (bukan menguji ketidaktahuan mahasiswa), show positive attitudes to their students (bersikap positif terhadap mahasiswa)

The law on lecturers and teachers (undang-undang Guru dan Dosen) has also explained that teachers must equip themselves with professional, pedagogic, personal, and social competences. A teacher who has these competences can create a classroom atmospheree, make the lesson easy which boost students' motivation and good attitude to the class/subject.

The change of curriculum from 2006 or KTSP curriculum to 2013 curriculum, which emphasizes on character education represented in its 
core competence demands teacher creativity in arranging learning activities highly. It is hoped that through learning activities students will not only get knowledge, but also attitude and action (pengetahuan, sikap, ketrampilan). This is explisitly mentioned and explained in the enclosure of the regulation of minister of education (Permendikbud) no. 54/2013 about graduation competence standard.

The 2013 curriculum also require teachers to implement scientific approach. Through this approach teachers are demanded to design learning activities which give more learning experience to students in their effort to understand the materials. Through this approach teachers are also required to integrate three domains of learning aims, i.e. cognitive, affective, and psychomotoric, which are in line with knowledge, attitude, and action.

Tomlinson (2003) is among experts who explain some characteristics of good language teachers. The characteristics are:

1. is patient and supportive

2. has a good sense of humor

3. is enthusiastic, positive, and confident

4. is interesting, stimulating, and creative

5. is a good communicator

6. is flexible and takes initiative

7. is sensitive to the needs and wants of her learners and teaches responsively

8. is critically aware of current theoretical and methodological developments

9. has a large and varied repertoire of pedagogical procedures

10. is proficient user of the target language 
11. has awareness of the realities of the target language and of the $\mathrm{L} 1$ and $\mathrm{L} 2$ cultures

Criteria 1, 2, 3 can be classified as personal competence and criteria 4, 5, 6, 7, 8, 9 belong to pedagogic competence, and 10, 11 deal with professional competence.

In term of material development, as a part of pedagogical competence which also supports a language teacher to be a good language teacher, Tomlinson (1998) states the following principals of material development:

1. provide rich and varied experience

2. provide variety of context specific beliefs

3. set achievable challenges

4. encourage cooperative learning

5. encourage peer monitoring and feedback

6. encourage reflection and self evaluation

7. provide constructive feedbacks

Other criteria of good language teacher can be mentioned here are (1) he must have good mastery of teaching materials, (2) have positive attitudes toward the target language, (3) must be patient, fair, and friendly, (4) know how to motivate students, (5) know how to deal with modern technology, (6) be able to activate students (I Gusti, 2007).

In a nutcell, a good teacher is a teacher who can become a good partner for his or her students in one side and become an information resource as well as a classroom manager in another side. 


\section{The roles of teachers in foreign language teaching}

Teachers is not a person who can do anything she or he wants in her or his class. Nevertheless it is still frequently said that a teacher is a ruler of the class. The following roles are those which should actually be played:

1. as an observer

2. as an assessor

3. as an organizer

4. as a facilitator

5. as a participant

6. as a source

(Harmer, 1983).

Like teachers in general, a good language teacher has to play his roles in line with his classroom situation or activity. If he is aware of all those roles he will create a logical sequence of activities in which he can change his role in one activity to another activity. The harmonious activities will make the class enjoyable for the students.

\section{Research method}

This research was quantitavely and qualitatively designed. It employed questionnaire as the main data collection techniques. That technique comprised closed and open-ended ones. The open ended questionnaire was functioned as triangulation of data collection technique. Meanwhile, the closed ended questionnaire was basically the main data collection technique aimed at getting the same data. Students were given enough time to express their judgment on their English and 
Arabic language teacher through both open and closed ended questionnaire.

This study was carried out at IAIN Walisongo. Data of this study were taken from students of all faculties, i.e. Education and Teacher Training and Dakwah and Communication, who had taken English or Arabic Language in their previous semesters. Their conceptions and perception are the representation of their judgment made based on their learning experience.

\section{Discussion}

Perception of students of education and teacher training faculty

Perception toward english language teachers

To gain information about students' perception toward English language teachers, researchers distributed questionnaire to the students from four departments, i.e. biology, chemistry, physics, and Islamic Elementary School Teacher Training.

\section{Professional competence}

In terms of characteristics relating to professional competence the data show that having good mastery of teaching materials gains the highest score. It is 2.7. Other characteristics representing professional competence are proficient user of the target language, has awareness of the realities of the target language, and doesn't see L1 and L2 as the different materials. Each of them gets 2.5, 1.5, 2.3. Those scores are summarized in tabel 1 below: 
Table 1

The Score of Professional Competence of English Language Teachers at Education and

Teacher Training Faculty

\begin{tabular}{|c|l|c|}
\hline No. & \multicolumn{1}{|c|}{$\begin{array}{c}\text { Characteristics } \\
\text { of Professional Competence }\end{array}$} & Score \\
\hline 1. & has good mastery of teaching materials & 2.7 \\
\hline 2. & is proficient user of the target language & 2.5 \\
\hline 3. & doesn't see L1 and L2 as the different ones & 1.5 \\
\hline 4. & has awareness of the realities of the target language & 2.3 \\
\hline \multicolumn{2}{|c|}{ Mean } & 2.25 \\
\hline
\end{tabular}

If it is seen from the ranks of 4 (strongly agree), 3 (agree), 2 (disagree), and 1 (strongly disagree), which also mean 4 (very good), 3 (good), 2 (good enough), 1 (bad) the score of 2.25 (mean) is categorized as good enough, which does not mean good. To gain this cathegory, it still needs 0.75 or nearly 1 . The score of 2.7 does not show that the English teachers teaching English 1, 2, and 3 at Education and Teacher Training Faculty have good mastery of the materials. If we trace back to the prerequisite of being English Teacher at this institution, such an impression or perception may not be given by the students. As can be seen, they are all have passed their graduate program, either from home or foreign universities. This perception may be influenced by their pedagogic competence. A teacher with good mastery of the materials without the support of good pedagogic competence will give unclear explanation of the materials and result in misunderstanding. More over, if the teachers look confused of making students understand, the perception that the materials is difficult, that the teachers do not master the materials well may be born. 
It is also shown that the teachers are also not proficient users of the target language, with the score of 2.5. In fact speaking is still hard for most of students and some teachers are also still hard to familiarize students with the oral use of the target language. To use the target language is actually not a problem for most of the English language teachers. But, it becomes a problem when the teachers fail to grade the language to students' levels. Moreover, if the class is too heterogeneous. This fact often results in the desicion to use English less than Indonesian language when explaining the materials. Students may see that case as the teachers' lack of competence in using oral English.

Most of the teachers has less awareness of the realities of the target language, and L1 and L2 as the different one as can be seen from the score of 1.5 and 2.3. It may be true since not all English language teachers have background of English Education. Some of them teach the language because they are considered as good language users either oral or written regardless their educational background. Cultural intgration and personalization is importan when we teach a foreign language. But any information about the target language is commonly interesting for the students. Moreover, information about the target language in context.

Students should also know in what way the native language and the target language are different. By comparing between both of them the area of learning difficulties may be predicted. Hence, based on this prediction, teachers set a strategic plan in the form of teaching learning activities which focus on that area. In a nut cell, identifying the difference between native and target language is highly demanded in teaching a foreign language. 
One thing wonder the researcher is the data from open-ended questionnaire. Mosts students said that their English teachers were good. Only little of the did not say so. Some of the prooves may be listed are: ... jelas, menguasai 'clear, master the materials' (FIS/I14-L), ... sabar, cakap, motivator yang baik 'patient, skillfull, good motivator' (FIS/I15$\mathrm{MR})$, ... tidak pernah berbahasa Inggris dan lebih mengajar tentang bahasa, bukan ketrampilan berbahasanya 'never speaks English and teach more about English, not language skill' (FIS/I14-AR), ... sabar, berbahasa Inggris dengan baik 'patient, speaks English well' (FIS/I20SL), menguasai materi .... 'master the materials' (PGMI/I4-MH) dan (PGMI/I6-RW), Berbahasa Inggris dengan baik dan lancar 'speaks English well and fluently' (BIO/I19-a).

\section{Pedagogic and social competence}

The scores of teachers' pedagogic competence are listed in the following table:

Table 2

The Score of Pedagogic and Sosial Competence of English Language Teachers at Education and Teacher Training Faculty

\begin{tabular}{|c|l|c|}
\hline No & \multicolumn{1}{|c|}{ Characteristics } & Score \\
\hline 1. & doesn't believe in students' ability & 2.7 \\
\hline 2. & is interesting, stimulating & 2.8 \\
\hline 3. & Is creative & 2.7 \\
\hline 4. & is a good communicator & 3.0 \\
\hline 5. & always teaches based on students' request & 2.0 \\
\hline 6. & is sensitive to the needs and wants of her learners & 2.2 \\
\hline 7. & teaches responsively & 2.6 \\
\hline
\end{tabular}




\begin{tabular}{|c|l|c|}
\hline 8. & $\begin{array}{l}\text { sometimes aware of current theoretical and } \\
\text { methodological developments }\end{array}$ & 2.7 \\
\hline 9. & $\begin{array}{l}\text { has a large and varied repertoire of pedagogical } \\
\text { procedures }\end{array}$ & 2.3 \\
\hline 10. & set hard challenges & 2.3 \\
\hline 11. & Encourage cooperative learning & 2.4 \\
\hline 12. & Encourage peer monitoring and feedback & 2.2 \\
\hline 13. & Encourage reflection and self evaluation & 2.3 \\
\hline 14. & provide constructive feedbacks & 2.2 \\
\hline 15 & is flexible and takes initiative & 2.3 \\
\hline \multicolumn{2}{|c|}{ Mean } & 2.3 \\
\hline
\end{tabular}

Data above ensure the previous prediction that the low score of teachers' professional competence may be tightly influenced by the teachers' pedagogic and sosial competence. It is shown by the mean of the competences which reaches only 2.3 , which is in fact less than ideal. Teachers' inability to convey the lesson clearly often result in the perception that the teachers do not master the materials well.

The lowest score is 2.0 representing teachers' frequency in accommodating students' request which says always teaches based on students' request. Although the score seems low but it is in fact the ideal score. When we teach, we are requested to consider students' request. But, we must note not to always hear their voice.

Before teaching teachers prepare syllabus and lesson plan. when they implement them, they are required to involve them in terms of choice of themes, activities learning sources. But we do that in line with our teaching learning plan.

The frequency of monitor, feedback, reflection and evaluation is also still low, from 2.2 to 2.3. teachers who seldom monitor students' 
activity will not be able to provide appropriate feedback. It's also impossible for the to conduct reflection and class evaluation.

Monitoring is one of crucial items in teaching learning process. It in fact needs energy and consumes time. When monitoring students' activity, teachers do not have time to do their "side busnisses" while students are working out their instruction. More over, if it is followed by correcting students' work. Although it's time consuming teachers should spend their portion of time to monitor and correct students' activities and work. This is they way how they will learn from their mistakes.

Referring to these competences, some of the data from openended questionnaire also say differently. Most students said that their teachers were good, professional who implemented varied methodes, taught for skills, knew students' condition, had fun class. They said, ... menggunakan metode bervariasi dan kelas yang menyenangkan 'uses varied methods and has fun class' (BIO/I12-a), ... kreatif, menarik, jelas, disiplin 'creative, interesting, clear, descipline' (BIO/I13-a), ... menarik, antusias, jelas, pembelajaran berbasis tugas 'interesting, enthusistic, clear, task-based learning' (BIO/15-AP), ... sangat baik, bisa menghidupkan kelas 'very good, capable of enlivening class' (KIM/I13ST), Mengimplementasikan cooperative learning 'Implementing cooperative learning' (KIM/I1-D), Enak 'Fun' (KIM/I29-S), Memenuhi kompetensi pedagogik .... 'Meet padagogic competence' (FIS/I2-SL), Jelas .... 'clear' (FIS/I14-L), ... kreatif dalam penyampaian dan manajemen kelas 'creative in delivering materias and managing class' (PGMI/I4-MH), Tanggap terhadap kondisi kelas dan tanggap terhadap karakter mahasiswa 'Responsive to the class condition and students' characteristics' (PGMI/I16-MR). 
Personality competence

The information about English language teachers' personality competence may be accessed from table 3 below:

Table 3

The Score of Personality Competence

of English Language Teachers

at Education and Teacher Training Faculty

\begin{tabular}{|c|l|c|}
\hline No. & \multicolumn{1}{|c|}{ Characteristics } & Score \\
\hline 1. & is patient and supportive & 2.4 \\
\hline 2. & doesn't have sense of humour & 2.2 \\
\hline 3. & is enthusiastic and confident & 2.2 \\
\hline \multicolumn{2}{|c|}{ Mean } & 2.3 \\
\hline
\end{tabular}

Just like the previous three competences, the data above proove that the average score of English language teachers' personality competence has not reached an ideal score, since it is less than 3.0. Although it is not a terrible score, the English teachers still need to improve their personality. They still needto be more patient and supportive, have sense of humour, enthusiatic and confident.

To change a person's personality is not an easy job, since it has usually been built from her/his family and closest environment. But it is not impossible for a person to have better personality, to suit with the requirement of her/his profession.

That process may be started from improving teachers' emphaty and care. Put ourselves in the position of others so that we can feel what others feel. Emphaty may boost our care, may make us more patient and supportive, and enthusiatic when handling our class. 
Some students had good perception about their English teachers' personality competence by expressing their opinion through the openended questionnaire. Some said that their teachers are Menarik, antusias, .... 'Interesting, enthusiastic' (BIO/I15-AP), Perhatian pada yang belum paham 'Give attention to those who are unclear' (BIO/I26-a), Enak 'Fun' (KIM/I29-a), Fleksibel, humoris, obyektif 'Flexible, has sense of humour, objective' (FIS/14-L), Sabar, cakap, motivator yang baik 'Patient, skillfull, good motivator' (FIS/I16-AM), Baik, sabar, suportif, jelas, .... 'Good, patient, supportive, clear' (PGMI/I10-AM), Sabar, inovatif 'patient, innovative' (PGMI/I17-NMA), Jelas, motivator yang baik, terbuka 'Clear, good motivator, open' (PGMI/I19-MU).

Perception toward arabic language teachers

The source of information about students' perception toward Arabic language teachers are students from other four departments of Education and Teacher Training Faculty, i.e. Islamic Education, Mathematics, Islamic Education Management, and Arabic Education.

\section{Professional competence}

The following data provide information about Arabic language teachers' professional competence with the average score of 2.7.

Table 4

The Score of Professional Competence of Arabic Language Teachers at Education and Teacher Training Faculty

\begin{tabular}{|c|c|c|}
\hline No. & $\begin{array}{c}\text { Characteristics } \\
\text { of Professional Competence }\end{array}$ & Score \\
\hline 1. & has good mastery of teaching materials & 3.2 \\
\hline
\end{tabular}




\begin{tabular}{|l|l|c|}
\hline 2. & is proficient user of the target language & 2.8 \\
\hline 3. & doesn't see L1 and L2 as the different ones & 2.0 \\
\hline 4. & has awareness of the realities of the target language & 2.8 \\
\hline \multicolumn{2}{|c|}{ Mean } & 2.7 \\
\hline
\end{tabular}

Table 4 shows that most Arabic language teachers at Education and Teacher Training Faculty have good mastery of teaching materials. They may also be cathegorized as teachers good Arabic language proficiency and awareness of the realities of the target language. This perception may be influenced by the good score of pedagogic competence.

Most of them are perceived not to see L1 and L2 as the different ones. Contrasting between native language and target language may raise students' awareness about the different features between all those two languages. Good awarenesss of the differences prevent students from transfering L1 language rules into the L2's they are learning. To conclude, that comparison will be a meaningful strategy in teaching a second or a foreign language.

Teachers with good mastery of the materials often impatient in delivering the materials gradually. The Arabic language teachers may also be impatience in highlighting the difference between the native language and the target language. That is why, students perceive that their teachers do not see L1 and L2 as the different one.

Most of data from open-ended aquestionnaire do support the above numerical data. Through this instrument most students also had positive perception to their arabic teachers' professional competence. Among all of them said, Menguasai .... 'Master the materials' (PAI/A12F), Menguasai, berpengalaman, .... 'Master the materials, experienced' 
(PAI/A21-Y), Memenuhi standar 'Meet the standards of a good teacher (KI/A12-SA), Menguasai materi, .... 'Master the materials' (KI/A15SA), ... mempunyai kemampuan linguistik ... ' ... has linguistic ability ....' (KI/A26-FA).

Pedagogic and social competence

The scores of teachers' pedagogic competence are listed in the following table:

Table 5

The Score of Pedagogic and Sosial Competence of Arabic Language Teachers at Education and Teacher Training Faculty

\begin{tabular}{|c|l|c|}
\hline No. & \multicolumn{1}{|c|}{ Characteristics } & Score \\
\hline 1. & doesn't believe in students' ability & 2.7 \\
\hline 2. & is interesting, stimulating & 2.8 \\
\hline 3. & Is creative & 2.7 \\
\hline 4. & is a good communicator & 3.0 \\
\hline 5. & always teaches based on students' request & 2.0 \\
\hline 6. & $\begin{array}{l}\text { is sensitive to the needs and wants of her } \\
\text { learners }\end{array}$ & 2.2 \\
\hline 7. & teaches responsively & 2.6 \\
\hline 8. & $\begin{array}{l}\text { sometimes aware of current theoretical and } \\
\text { methodological developments }\end{array}$ & 2.7 \\
\hline 9. & $\begin{array}{l}\text { has a large and varied repertoire of pedagogic } \\
\text { procedures }\end{array}$ & 2.8 \\
\hline 10. & set hard challenges & 2.7 \\
\hline 11. & Encourage cooperative learning & 2.7 \\
\hline 12. & Encourage peer monitoring and feedback & 2.6 \\
\hline 13. & Encourage reflection and self evaluation & 2.7 \\
\hline 14. & provide constructive feedbacks & 2.6 \\
\hline 15 & is flexible and takes initiative & 2.8 \\
\hline \multicolumn{2}{|l|}{ Mean } & 2.7 \\
\hline
\end{tabular}


The average score of pedagogic and social competence of Arabic language teachers at Education and Teacher Training Faculty is relatively good. Most of them are good communicator. It means that they can convey their learning materials well. Students' understanding is facilitated by their explanation.

They also do not always involve students in setting teaching poicies. Score 2.0 means that they keep the ballance between students' involvement and teachers' authority in setting them.

Most of the teachers are also interesting, stimulating, have varied repertoire of pedagogic procedures, flexible and take initiative. Data from open-ended questionnaire seem not to support the above data. Most students of Islamic education Department (PAI) wrote that their teachers' explanation is ununderstandable, teacher has less attention to the slow learners, monotonous class - “... kurang memahami kekurangan mahasiswa" (PAI/A4-MI), “... belum baik, belum memahamkan” (PAI/A6-N), “... kurang memahamkan, tidak sesuai kontrak belajar” (PAI/A12-F), “... menguasai, berpengalaman, tapi anggap mahasiswa berkemampuan sama," (PAI/A21-Y) , “Metode kurang, hanya menghafal, kadang monoton” (PAI/A26-N), “... tidak menghiraukan yang belum bisa" (PAI/A26-M).

Unlike students of Islamic Education Department, students from Mathematics, Arabic, and Islamic Education Management said differently about their Arabic language teachers. Their Arabic language teachers are patient, supportive, fun, creative, humorist, qualified, have good commitment, methode, classroom management, ... Their teachers are ... sabar, suportif, menyenangkan 'patient, supportive, fun' (KI/A1$\mathrm{ZR})$, ... berkomitmen, tepat waktu 'has commitment, on time' (KI/A1- 
AI), ... kuasai kelas, materi, metode 'manage the class, master the materials and methods' (KI/A5-FA), ... semangat, menarik 'enthusiatic, interesting' (KI/A16-SA), ... sabar, membimbing 'patient, guide' (KI/A17-YR), ... jelas, menguasai metode, banyak inisiatif 'clear, master teaching methods, has good initiative' (PBA/A12-F), ... komunikatif, paham situasi mahasiswa, fasih 'communicative, understand students' condition, speaks fluently' (PBA/A23-NMU), ... sabar, suportif, variatif, sistematis 'patient, supportive, variative, sistematic' (TM/A11-F), ... pengertian, sabar, toleran 'understand students' condition, patient, tolerant' (TM/A12-AH).

Personality competence

Table 6 provides information about Arabic language teachers' personality competence.

\section{Table 6}

The Score of Personality Competence

of English Language Teachers

at Education and Teacher Training Faculty

\begin{tabular}{|c|l|c|}
\hline No. & \multicolumn{1}{|c|}{ Characteristics } & Score \\
\hline 1. & is patient and supportive & 2.9 \\
\hline 2. & doesn't have sense of humor & 2.7 \\
\hline 3. & is enthusiastic and confident & 2.7 \\
\hline & Mean & 2.76 \\
\hline
\end{tabular}

From table 6 it is proven that most of the Arabic language teachers have considerably good personality competence. Although the score is less than but closes to 3.0.

Personality may be the first thing which creates good impression, triggers and stimulates positive attitude to the language learning. 
Personality is actually innnate, but it may be changed and developed, although it is hard.

The data from open-ended questionnaire support the numerical data above. Some of them are, sabar, suportif, variatif, sistematis 'patient, supportive, variative, systematic' (TM/A-F), pengertian, sabar, toleran 'understand students' condition, patient, tolerant' (TM/A12-AH), sabar, suportif, menyenangkan 'patient, supportive, fun' (KI/A1-ZR), sabar, kreatif, humoris 'patient, creative, has sense of humour' (KI/A10UN), sabar, kreatif, menarik, jelas 'patient, creative, interesting, clear' (PAI/A4-Mi), sabar, baik, suasana cair 'patient, good, fun' (PAI/A5MT), tahu kondisi mhs, motivator 'understand students' condition, motivator' (PBA/A28-MNU).

Perception toward english and arabic language teachers: a brief comparison

To highlight clearly the difference between the students' perception toward English and Arabic Language Teachers at Education and Teacher Training Faculty, the researcher need to provide the following data:

Table 7

The Score of Students' Perception toward English and Arabic Language Teachers at Education and Teacher Training Faculty

\begin{tabular}{|l|l|l|l|l|l|l|l|l|l|l|l|}
\hline & \multicolumn{10}{|c|}{ Characteristics } \\
\cline { 2 - 12 } & 1 & 2 & 3 & 4 & 5 & 6 & 7 & 8 & 9 & 10 & 11 \\
\hline E & 2.4 & 2.2 & 2.2 & 2.3 & 2.3 & 2.3 & 2.7 & 2.6 & 1.8 & 1.7 & 2 \\
\hline A & 2.9 & 2.7 & 2.7 & 2.7 & 2.8 & 2.7 & 3.2 & 3 & 2 & 2.2 & 2.6 \\
\hline
\end{tabular}




\begin{tabular}{|l|l|l|l|l|l|l|l|l|l|l|l|}
\hline & \multicolumn{11}{|c|}{ Characteristics } \\
\cline { 2 - 12 } & 12 & 13 & 14 & 15 & 16 & 17 & 18 & 19 & 20 & 21 & 22 \\
\hline $\mathrm{E}$ & 2.2 & 2.3 & 2.5 & 1.5 & 2.3 & 2.4 & 2.2 & 2.3 & 2.2 & 2.3 & 2.3 \\
\hline $\mathrm{A}$ & 2.7 & 2.8 & 2.8 & 2 & 2.7 & 2.7 & 2.6 & 2.7 & 2.6 & 2.8 & 2.8 \\
\hline
\end{tabular}

If it is seen in detail, table 7 shows that in all characteristics Arabic language teachers are dominating. Arabic language teachers win 0.5 over English language teachers in almost all characteristics.

Meanwhile, the data from each department may be listed as follow:

Table 8

The Score of Students' Perception toward English and Arabic Language Teachers from the Departments at Education and Teacher Training Faculty

\begin{tabular}{|l|l|c|}
\hline $\begin{array}{c}\text { Teachers' } \\
\text { Subject }\end{array}$ & \multicolumn{1}{|c|}{ Department } & Average Score \\
\hline English & Biology & 2 \\
\hline \multirow{5}{*}{} & Chemistry & 3 \\
\cline { 2 - 3 } & Physics & 2 \\
\cline { 2 - 3 } & $\begin{array}{l}\text { Islamic Elementary } \\
\text { Teacher Training }\end{array}$ & 2 \\
\hline Arabic & Islamic Education & 2 \\
\hline \multirow{2}{*}{} & Mathematics & 2 \\
\cline { 2 - 3 } & $\begin{array}{l}\text { Islamic Education } \\
\text { Management }\end{array}$ & 3 \\
\cline { 2 - 3 } & Arabic Education & 3 \\
\hline
\end{tabular}

It is clearly seen that chemistry department students have better perception to their English language teachers. Meanwhile, students who have better perception to their Arabic Language Teachers are those from Islamic Education Management and Arabic Education Departments. 
The above conclusion does not mean that teachers who teach chemistry, Islamic Education Management and Arabic Education Departments students are more qualified than those who teach the rest of students, since the English and the Arabic classes are mixed. The students are classified based on their intake rather than their department.

\section{Perception of students of dakwah and communication faculty}

Perception toward english language teachers

To gain information about students' perception toward English language teachers, researchers distributed questionnaire to the students from four departments, i.e. KPI, BPI and $M D$.

\section{Professional competence}

In terms of characteristics relating to professional competence the data show that having good mastery of teaching materials gains the highest score. It is 3.2. Other characteristics representing professional competence are proficient user of the target language, has awareness of the realities of the target language, and doesn't see L1 and L2 as the different materials. Each of them gets 2.7, 2.2, 3.1. Those scores are summarized in tabel 1 below:

Table 1

The Score of Professional Competence of English Language Teachers at Dakwah and Communication Faculty

\begin{tabular}{|l|l|l|}
\hline No. & \multicolumn{1}{|c|}{$\begin{array}{c}\text { Characteristics } \\
\text { of Professional Competence }\end{array}$} & Score \\
\hline 1. & has good mastery of teaching materials & 3.2 \\
\hline 2. & is proficient user of the target language & 2.7 \\
\hline
\end{tabular}




\begin{tabular}{|l|l|l|}
\hline 3. & doesn't see L1 and L2 as the different ones & 2.2 \\
\hline 4. & $\begin{array}{l}\text { has awareness of the realities of the target } \\
\text { language }\end{array}$ & 3.1 \\
\hline \multicolumn{2}{|c|}{ Mean (11.2:4) } & 2.8 \\
\hline
\end{tabular}

If it is seen from the ranks of 4 (strongly agree), 3 (agree), 2 (disagree), and 1 (strongly disagree), which also mean 4 (very good), 3 (good), 2 (good enough), 1 (bad) the score of 2.8 (mean) is categorized as good. The score of 3.2 shows that the English teachers teaching English 1, 2, and 3 at Dakwah Faculty have good mastery of the materials. As can be seen that a teacher who has good mastery of the materials with the support of good pedagogic competence will give clear explanation of the materials and good result. It indicates that the perception of students toward the teachers is good.

On the contrary, it is shown that the teachers are not proficient users of the target language, with the score of 2.7. In fact speaking is still hard for most of students and some teachers are also still hard to familiarize students with the oral use of the target language. To use the target language is actually not a problem for most of the English language teachers. But, it becomes a problem when the teachers fail to grade the language to students' levels. Moreover, if the class is too heterogeneous. This fact often results in the desicion to use English less than Indonesian language when explaining the materials. Students may see that case as the teachers' lack of competence in using oral English.

Most of the teachers has less awareness of the realities of the target language, and L1 and L2 as the different one as can be seen from the score of 2.2 and 3.1 It may be true since not all English language teachers have background of English Education. Some of them teach the 
language because they are considered as good language users either oral or written regardless their educational background. Cultural intgration and personalization is important when we teach a foreign language. But any information about the target language is commonly interesting for the students. Moreover, information about the target language in context.

Students should also know in what way the native language and the target language are different. By comparing between both of them the area of learning difficulties may be predicted. Hence, based on this prediction, teachers set a strategic plan in the form of teaching learning activities which focus on that area. In a nut cell, identifying the difference between native and target language is highly demanded in teaching a foreign language.

One thing wonder the researcher is the data from open-ended questionnaire. Mosts students said that their English teachers were good. Only little of the did not say so. Some of the prooves may be listed are: ... jelas, menguasai 'clear, master the materials' (FD/BPI), ... sabar, cakap, motivator yang baik 'patient, skillfull, good motivator', ... tidak pernah berbahasa Inggris dan lebih mengajar tentang bahasa, bukan ketrampilan berbahasanya 'never use English, teaches about language not language skill' (FD/KPI), ... sabar, berbahasa Inggris dengan baik 'patient, speaks English well', Berbahasa Inggris dengan baik dan lancar 'Speaks English well and fluently' (FD/MD).

\section{Pedagogic and social competence}

The scores of teachers' pedagogic competence are listed in the following table: 
Table 2

The Score of Pedagogic and Sosial Competence of English Language Teachers at Dakwah and Communication Faculty

\begin{tabular}{|c|l|c|}
\hline No. & \multicolumn{1}{|c|}{ Characteristics } & Score \\
\hline 1. & doesn't believe in students' ability & 2.7 \\
\hline 2. & is interesting, stimulating & 2.8 \\
\hline 3. & Is creative & 2.9 \\
\hline 4. & is a good communicator & 2.9 \\
\hline 5. & always teaches based on students' request & 2.5 \\
\hline 6. & $\begin{array}{l}\text { is sensitive to the needs and wants of her } \\
\text { learners }\end{array}$ & 2.7 \\
\hline 7. & teaches responsively & 2.8 \\
\hline 8. & $\begin{array}{l}\text { sometimes aware of current theoretical and } \\
\text { methodological developments }\end{array}$ & 2.7 \\
\hline 9. & $\begin{array}{l}\text { has a large and varied repertoire of pedagogical } \\
\text { procedures }\end{array}$ & 3.0 \\
\hline 10. & set hard challenges & 2.9 \\
\hline 11. & Encourage cooperative learning & 2.7 \\
\hline 12. & Encourage peer monitoring and feedback & 2.9 \\
\hline 13. & Encourage reflection and self evaluation & 2.9 \\
\hline 14. & provide constructive feedbacks & 2.8 \\
\hline 15 & is flexible and takes initiative & 3.0 \\
\hline & Mean (42.2 $: 15$ ) & 2.8 \\
\hline
\end{tabular}

Data above ensure the previous prediction that the low score of teachers' professional competence may be tightly influenced by the teachers' pedagogic and sosial competence. It is shown by the mean of the competences which reaches 2.8, which is in fact less than ideal (good enough). Teachers' inability to convey the lesson clearly often result in the perception that the teachers do not master the materials well.

The lowest score is 2.5 representing teachers' frequency in accommodating students' request which says always teaches based on 
students' request. Although the score seems quite low but it is in fact the ideal score. When we teach, we are requested to consider students' request. But, we must note not to always hear their voice.

Before teaching teachers prepare syllabus and lesson plan. when they implement them, they are required to involve them in terms of choice of themes, activities learning sources. In fact, we do that in line with our teaching learning plan.

The frequency of monitor, feedback, reflection and evaluation is good enough, from 2.8 to 2.9. teachers who seldom monitor students' activity will not be able to provide appropriate feedback. It's also impossible for the to conduct reflection and class evaluation. It needs improvement to have a good result.

Monitoring is one of crucial items in teaching learning process. It in fact needs energy and consumes time. When monitoring students' activity, teachers do not have time to do their "side busnisses" while students are working out their instruction. More over, if it is followed by correcting students' work. Although it's time consuming teachers should spend their portion of time to monitor and correct students' activities and work. This is they way how they will learn from their mistakes.

Referring to these competences, some of the data from openended questionnaire also say good. Most students said that their teachers were good, professional who implemented varied methodes, taught for skills, knew students' condition, had fun class. They said, ... menggunakan metode bervariasi dan kelas yang menyenangkan 'uses varied methods and has fun class', ... kreatif, lumayan menarik, jelas 'creative, interesting enough, clear' (FD/BPI), ... kreatif dalam penyampaian dan manajemen kelas 'creative in delivering materials and 
managing class (FD/KPI), Tanggap terhadap kondisi kelas dan tanggap terhadap karakter mahasiswa 'Responsive to the class condition and students' characters' (FD/MD).

Personality competence

The information about English language teachers' personality competence may be accessed from table 3 below:

Table 3

The Score of Personality Competence of English Language Teachers at Dakwah and Communication Faculty

\begin{tabular}{|c|l|c|}
\hline No. & \multicolumn{1}{|c|}{ Characteristics } & Score \\
\hline 1. & is patient and supportive & 3.1 \\
\hline 2. & doesn't have sense of humour & 2.7 \\
\hline 3. & is enthusiastic and confident & 3.5 \\
\hline \multicolumn{2}{r|}{ Mean $(9.3: 3)$} & 3.1 \\
\hline
\end{tabular}

Different from the previous three competences that the data above proove that the average scores of English language teachers' personality competence has not reached an ideal score, since it is less than 3.0. This table of Personality shows that their personalities are good. They are not only patient and supportive, but also enthusiatic and confident. Even though teachers' emphaty and care, patient, supportive, and enthusiatic when handling our class in fact (based on the data above) they are less sense of humor in a classroom.

Perception toward arabic language teachers

The source of information about students' perception toward Arabic language teachers are students from other three departments of Dakwah and Communication Faculty, i.e. KPI, BPI, and MD. 


\section{Professional competence}

The following data provide information about Arabic language teachers' professional competence with the average score of 2.7.

\section{Table 4}

The Score of Professional Competence

of Arabic Language Teachers

at Dakwah and Communication Faculty

\begin{tabular}{|c|l|c|}
\hline No. & \multicolumn{1}{|c|}{$\begin{array}{c}\text { Characteristics } \\
\text { of Professional Competence }\end{array}$} & Score \\
\hline 1. & has good mastery of teaching materials & 3.2 \\
\hline 2. & is proficient user of the target language & 2.6 \\
\hline 3. & doesn't see L1 and L2 as the different ones & 2.2 \\
\hline 4. & has awareness of the realities of the target language & 3.0 \\
\hline \multicolumn{2}{|r|}{ Mean (11:4 ) } & 2.8 \\
\hline
\end{tabular}

Table 4 shows that most Arabic language teachers at Dakwah and Communication Faculty have good mastery of teaching materials. They may also be cathegorized as teachers good Arabic language proficiency and awareness of the realities of the target language. This perception may be influenced by the good score of pedagogic competence.

Most of them are perceived not to see L1 and L2 as the different ones. Contrasting between native language and target language may raise students' awareness about the different features between all those two languages. Good awarenesss of the differences prevent students from transfering L1 language rules into the L2's they are learning. To conclude, that comparison will be a meaningful strategy in teaching a second or a foreign language. 
Teachers with good mastery of the materials often impatient in delivering the materials gradually. The Arabic language teachers may also be impatience in highlighting the difference between the native language and the target language. That is why, students perceive that their teachers do not see L1 and L2 as the different one.

Most of data from open-ended aquestionnaire do support the above numerical data. Through this instrument most students also had positive perception to their arabic teachers' professional competence. Among all of them said, Menguasai materi 'Master the materials', berpengalaman 'berpengalaman', Memenuhi standar 'Meet the standards $(\mathrm{FD} / K P I, B P I, M D)$.

\section{Pedagogic and social competence}

The scores of teachers' pedagogic competence are listed in the following table:

Table 5

The Score of Pedagogic and Sosial Competence

of Arabic Language Teachers

at Dakwah and Communication Faculty

\begin{tabular}{|c|l|c|}
\hline No. & \multicolumn{1}{|c|}{ Characteristics } & Score \\
\hline 1. & doesn't believe in students' ability & 2.8 \\
\hline 2. & is interesting, stimulating & 2.8 \\
\hline 3. & Is creative & 2.8 \\
\hline 4. & is a good communicator & 2.9 \\
\hline 5. & always teaches based on students' request & 2.7 \\
\hline 6. & is sensitive to the needs and wants of her learners & 2.8 \\
\hline 7. & teaches responsively & 2.7 \\
\hline 8. & $\begin{array}{l}\text { sometimes aware of current theoretical and } \\
\text { methodological developments }\end{array}$ & 3.1 \\
\hline 9. & $\begin{array}{l}\text { has a large and varied repertoire of pedagogic } \\
\text { procedures }\end{array}$ & 2.9 \\
\hline
\end{tabular}




\begin{tabular}{|c|l|l|}
\hline 10. & set hard challenges & 2.8 \\
\hline 11. & Encourage cooperative learning & 2.7 \\
\hline 12. & Encourage peer monitoring and feedback & 2.7 \\
\hline 13. & Encourage reflection and self evaluation & 2.8 \\
\hline 14. & provide constructive feedbacks & 2.7 \\
\hline 15 & is flexible and takes initiative & 2.8 \\
\hline \multicolumn{2}{|l|}{ Mean $(42: 15)$} & 2.8 \\
\hline
\end{tabular}

The average score of pedagogic and social competence of Arabic language teachers at Dakwah and Communication Faculty is relatively good. Most of them are good communicator. It means that they can convey their learning materials well. Students' understanding is facilitated by their explanation.

They also do not always involve students in setting teaching policies. Score 2.8 means that they keep the ballance between students' involvement and teachers' authority in setting them.

Most of the teachers are also interesting, stimulating, have varied repertoire of pedagogic procedures, flexible and take initiative. Data from open-ended questionnaire seem not to support the above data. Most students of Islamic Broadcasting and Communication Department (KPI) wrote that their teachers' explanation is ununderstandable, teacher has less attention to the slow learners, monotonous class (FD/BPI,KPI,MD).

Some students also said about their Arabic language teachers. Their Arabic language teachers are patient, supportive, fun, creative, humorist, qualified, have good commitment, methode, classroom management.

\section{Personality competence}

Table 6 provides information about Arabic language teachers' personality competence. 
Table 6

The Score of Personality Competence

of English Language Teachers

at Dakwah and Communication Faculty

\begin{tabular}{|c|c|c|}
\hline No. & Characteristics & Score \\
\hline 1. & is patient and supportive & 3.0 \\
\hline 2. & doesn't have sense of humour & 2.8 \\
\hline 3. & is enthusiastic and confident & 3.4 \\
\hline & Mean $(9.2: 3)$ & 3.1 \\
\hline
\end{tabular}

From table 6 it is proven that most of the Arabic language teachers have considerably good personality competence. Personality may be the first thing which creates good impression, triggers and stimulates positive attitude to the language learning. Personality is actually innnate, but it may be changed and developed, although it is hard.

Perception toward english and arabic language teachers: a brief comparison

To highlight clearly the difference between the students' perception toward English and Arabic Language Teachers at Dakwah and Communication Faculty, the researcher need to provide the following data:

Table 7

The Score of Students' Perception toward English and Arabic Language

Teachers at Dakwah and Communication Faculty

\begin{tabular}{|l|l|l|l|l|l|l|l|l|l|l|l|}
\hline & \multicolumn{10}{c|}{ Characteristics } \\
\hline & 1 & 2 & 3 & 4 & 5 & 6 & 7 & 8 & 9 & 10 & 11 \\
\hline E & 2.4 & 2.2 & 2.2 & 2.7 & 2.8 & 2.9 & 3.2 & 2.9 & 2.5 & 2.7 & 2.8 \\
\hline A & 2.9 & 2.7 & 2.7 & 2.8 & 2.8 & 2.8 & 3.2 & 2.9 & 2.7 & 2.8 & 2.7 \\
\hline
\end{tabular}




\begin{tabular}{|l|l|l|l|l|l|l|l|l|l|l|l|}
\hline & \multicolumn{10}{|c|}{ Characteristics } \\
\cline { 2 - 12 } & 12 & 13 & 14 & 15 & 16 & 17 & 18 & 19 & 20 & 21 & 22 \\
\hline E & 3.0 & 2.9 & 2.7 & 2.2 & 2.7 & 2.9 & 2.9 & 2.9 & 2.8 & 3.0 & 3.1 \\
\hline A & 3.1 & 2.9 & 2.6 & 2.2 & 2.8 & 2.7 & 2.7 & 2.8 & 2.7 & 2.8 & 3.0 \\
\hline
\end{tabular}

If it is seen in detail, table 7 shows that in all characteristics English language teachers are dominating. English language teachers win 0.5 over Arabic language teachers in almost all characteristics.

Meanwhile, the data from each department may be listed as follow:

Table 8

The Score of Students' Perception toward English and Arabic Language Teachers from the Departments at Dakwah and Communication Faculty

\begin{tabular}{|l|l|c|}
\hline $\begin{array}{c}\text { Teachers' } \\
\text { Subject }\end{array}$ & Department & Average Score \\
\hline English & BPI & 3.0 \\
\hline & KPI & 2.8 \\
\cline { 2 - 3 } & MD & 2.7 \\
\hline Arabic & BPI & 2.9 \\
\hline & KPI & 2.7 \\
\cline { 2 - 3 } & MD & 2.6 \\
\hline
\end{tabular}

It is clearly seen that KPI (Islamic Communication \& Broadcasting) department students have better perception to their English language teachers. Meanwhile, students who have better perception to their Arabic Language Teachers are those from Islamic Counseling Departments (BPI).

The above conclusion does not mean that teachers who teach KPI, and MD Departments students are more qualified than those who teach the rest of students, since the English and the Arabic classes are mixed. 
The students are classified based on their intake rather than their department.

\section{References}

Ani Purjayanti. 2007. "The 'Good Language Teacher': Students' Perspectives. Human Resources Development in English Language Teaching: The $55^{\text {th }}$ TEFLIN Conference Proceedings. December 46, 2007.

Direktorat Jenderal Pendidikan Tinggi (Dikti). 2006. Sosialisasi Tim Dikti. Kurikulum Berbasis Kompetensi (KBK)

Hoffman, Donald D. The Interface theory of Perception to Swift Extinction. www.cogsci.uci.edu/ ddhoff/interface.pdf. Accessed on October 10, 2013

Kementerian Pendidikan dan Kebudayaan: Permendikbud no. 65/2013 Tomlinson, Brian (ed). 1998. Material Development in Language Teaching. Cambridge: Cambridge University Press.

Tomlinson, Brian. 2003. Developing Materials to Develop Yourself Teaching. London: Continuum Press.

Harmer, Jeremy. 1983. The Practice of English Language Teaching. London \& New York: Longman

Hay McBer Consultants. 2000. Research in Teaching Effectiveness. A summary report to the Department for Education and Employment, United Kingdom. Retrieved September 14, 2005 ,from http://www.teachernet.gov.uk/doc/1487/haymcber.doc.

I Gusti Ayu GS. 2007. "Good Language Teacher in the Era of Globalization." Human Resources Development in English Language Teaching: The 55 ${ }^{\text {th }}$ TEFLIN Conference Proceedings. December 4-6, 2007.

Listyani. 2007. "What is a Good Language Teacher? An Overview of Students' and Teachers' Reflection." Human Resources Development in English Language Teaching: The 55 ${ }^{\text {th }}$ TEFLIN Conference Proceedings. December 4-6, 2007.

Zhang, Qunying and Davit Watkins. "Conceptions of a Good Tertiary EFL Teachers in China" in Tesol Quaterly Vol. 4 No. 4, December 2007 
